\title{
ПРОЦЕССУАЛЬНОЕ ПОЛОЖЕНИЕ СВИДЕТЕЛЯ ПО УСТАВУ УГОЛОВНОГО СУДОПРОИЗВОДСТВА
}

Аннотация: Статья посвящена законодательной регламентации процессуального статуса сви детеля, его освобождения от обязанности свидетельствовать, особенностям и условиям допроса на следствии и в суде в Уставе уголовного судопроизводства. В связи с отсутствием понятия свидетеля в УУС дается характеристика различных определений свидетеля, данных в трудах дореволюционных ученых-процессуалистов. Анализируются нормы УУС, освобождавшие свидетелей от дачи показаний, основания этого освобождения. Кроме этого приводятся и комментируются положения Проекта УУС, разработанного в 1900 г. Исследуются положения УУС, касающиеся дачи показаний свидетелями под присягой на следствии и в суде, дается характеристика значимости присяги, данная в трудах дореволючионных русских процессуалистов. Автором использован метод исторического анализа положений УУС, а также сравнительно-правовой метод, позволивший определить как законодательный подход к регулированию правового положения свидетеля, так и научные мнения по различным аспектам процессуального статуса свидетеля. В статье впервые дан конкретный анализ норм УУС, посвященных процессуальному статусу свидетеля, правилам его допроса на предварительном следствии и в суде, а также значения и роли присяги свидетеля для обеспечения достоверности показаний. На основании проведенного анализа норм УУС формулируется вывод: именно УУС заложил основы современного института свидетельствования в уголовном судопроизводстве, многие его положения восприняты УПК РФ.

Ключевые слова: Устав уголовного судопроизводства, Судебная реформа, свидетель, освобождение от свидетельствования, свидетельский иммунитет, допрос свидетеля, присяга свидетеля, освобождение от присяги, показания свидетеля, поверенный.

DOI: 10.7256/1994-1471.2014.4.11149

«Свидетели - альфа и омега уголовного процесса»

А.В. Скопинский

Устав уголовного судопроизводства (далее УУС) в сравнении с предыдущим законодательством привел в определенную и достаточно четкую систему нормы, регулировавшие процессуальное положение свидетеля. Вместе с тем, нормы, в которых бы давалось понятие свидетеля и определялись требования, предъявляемые к свидетелям, отсутствовали.

Русские ученые-процессуалисты давали различные определения свидетеля. И.Я. Фойницкий исходил из того, что свидетель есть «физическое лицо, имеющее об обстоятельствах производимого в суде дела сведения, добытые путем личного их наблюдения и призванное к суду, для удостоверения пред ним этих обстоятельств в установленном законом порядке» ${ }^{1}$.

Фойницкий И.Я. Курс уголовного судопроизводства:
П.В. Макалинский полагал, что свидетелями являются «лица, могущие дать показания в пользу или против обвиняемых, или же относительно состава преступления» ${ }^{2}$.

По мнению В.К. Случевского, свидетелями по делу могли быть «все лица, которые в состоянии дать судебной власти полезные указания к обнаружению материальной истины в отношении совершившегося преступления посредством изложения всего виденного или слышанного по делу»³. Из приведенных определений можно сделать вывод, что главным признаком свидетеля считалась его способность дать показания о том, что им виделось или слышалось.

В 2-х тт. Том 2. СПб., 1912. С. 266.

2 Макалинский П.В. Практическое руководство для судебных следователей, состоящих при окружных судах: В 2-х чч. Часть І. СПб.,1894. С. 234.

3 Случевский В.К. Учебник русского уголовного процесса: судоустройство: В 2-х чч. Часть І. СПб., 1891. С. 427.

(C) Смолькова Ираида Вячеславовна

Доктор юридических наук, профессор кафедры уголовного процесса и прокурорского надзора, Байкальский государственный университет экономики и права

[kupik@isea.ru]

664003, Россия, г. Иркутск, ул. Ленина, д. 11, каб. 6-301. 
Некоторые категории лиц по УУС освобождались от свидетельствования. В Объяснительной записке к УУС по данному поводу отмечалось: «следовало бы не отстранять никого от свидетельства, предоставить благоразумию судей определение значения каждого показания соответственно степени его достоверности; изъятие из этого правила может быть допущено только для тех случаев, когда свидетель по своим душевным или телесным недостаткам не мог познать свидетельствуемого предмета или же когда показание его против подсудимого было бы нарушением тайны, вверенной свидетелю такого звания, в котором он может приносить пользу обществу лишь при надлежащем доверии к его скромности» ${ }^{4}$. Эти мотивы и были положены в основу ст. 704 УУС.

Так, в соответствии со ст. 704 УУС не допускались к даче свидетельских показаний: «1) безумные и сумасшедшие; 2) духовные лица в отношении к признанию, сделанному им на исповеди; 3) присяжные поверенные и другие лица, исполнявшие обязанности защитников подсудимых - в отношении к признанию, сделанному им доверителями во время производства о них дела».

Оценивая запрет допрашивать в качестве свидетелей «безумных и сумасшедших», Правительствующий Сенат отметил, что «было бы совершенно несогласно с достоинством правосудия пользоваться для его целей источниками, явно ненадежными или опасными для общественной нравственности, а к таким источникам, несомненно, принадлежат показания лиц, кои по душевным недостаткам не могли показать свидетельствуемого предмета». А.В. Скопинский подверг критике данное суждение, заметив, что «некоторые психически ненормальные лица могут давать осмысленные показания» 5 .

В последующем Комиссия, специально созданная для пересмотра законоположений УУС, признала целесообразным упразднить исключение из числа свидетелей психически больных, исходя из того, что «на практике провести грань между слабоумными и безумными иногда прямо-таки невозможно ... а умалишенные могут иногда верно передать событие, с ними или при них случившееся». На этом основании в Проекте новой редакции УУС, подготовленном данной Комиссией, была предложена следующая формулировка: «Безумные, сумасшедшие и слабоумные не допрашивают-

Судебные уставы 20 ноября 1864 года с изложением рассуждений, на коих они основаны: В 4-х чч. Часть Вторая. СПб., 1866. С. 255.

Скопинский А.В. Свидетели по уголовным делам. М., 1911. C. 28. ся в качестве свидетелей; но для разъяснения дела судья, производящий следствие, может, по соображениям с состоянием их умственных способностей, расспрашивать этих лиц по возможности, при содействии врача, ни в каком случае не приводя их к присяге» (ст. 371) ${ }^{6}$.

«Безумных и сумасшедших» не допускали к свидетельству исходя из того, что они не могли быть приведены к присяге. Священники и присяжные поверенные освобождались от свидетельства в силу доверительных отношений с подсудимым, которые складываются при исполнении ими своих обязанностей.

Небезынтересно отметить, что при обсуждении Проекта УУС предлагалось не допускать священников к свидетельству «в отношении к признанию, сделанном им на исповеди или при подаче духовной помощи». При обсуждении же данного Проекта Государственный Совет признал, что «случаи и способы подания духовной помощи, если они выходят из пределов исповеди, могут быть весьма разнообразны и неопределенны, и недопущение в сих случаях к свидетельству священников могло бы послужить препятствием к раскрытию истины» ${ }^{7}$.

В дореволюционной юридической литературе существовала позиция, в соответствии с которой «если кающийся уполномочил духовника заявить о данном им ранее неправильном показании, могущем повлечь за собою наказание невиновного, устранение свидетельского показания священника могло послужить препятствием к раскрытию истины ${ }^{8}$.

Данная позиция подверглась обоснованной критике. Так, блестящий мастер слова А.Ф. Кони в этой связи писал: «попытки судебных практиков прямо отменить или косвенно обойти правила о недопросе священника относительно исповеди, в интересах успешного уголовного преследования, не могут вызывать сочувствия: они стремятся сделать таинственное общение человека с Богом орудием земного правосудия, освобождая его представителей от труда над раскрытием истины общепринятыми способами»9.

Освобождались от дачи свидетельских показаний и присяжные поверенные. В русском дореволюционном уголовном процессе адвокат, защитник обвиняемого (подсудимого),

\footnotetext{
Проект новой редакции Устава уголовного судопроизводства, составленный Высочайше утвержденною комиссией для пересмотра законоположений по судебной части. СПб., 1900. С. 225.

Судебные уставы 20 ноября 1864 года. С. 255.

8 Скопинский А.В. Указ. соч. С. 31.

Энциклопедический словарь / Ф.А. Брокгауз, И.А. Ефрон. В 82-х тт. Том 64. СПб., 1901. С. 494.
} 
именовался присяжным поверенным. Согласно Словарю русского языка С.И. Ожегова поверенный - лицо, официально уполномоченное действовать от чьего-нибудь имени; тот, кому доверена тайна, секрет; а присяжный - связанный присягой, клятвой ${ }^{10}$. Таким образом, присяжный поверенный - это лицо, связанное клятвой хранить тайну доверившегося ему человека и официально представляющий его права и законные интересы.

Дореволюционные процессуалисты, обосновывая наделение защитника свидетельским иммунитетом, исходили из разных причин недопустимости совмещения процессуального статуса свидетеля и защитника. А. Квачевский находил основания освобождения защитника от свидетельства в «соблюдении условия хранить тайну, вверенную лицу такого звания, в котором он может приносить пользу обществу лишь при надлежащем доверии к его скромности» ${ }^{11}$.

С.И. Викторский в этом вопросе исходил из соотношения публичных и частных начал уголовного судопроизводства, полагая, что «исключение присяжных поверенных из числа свидетелей составляет подчинение публичного интереса интересам частного лица» ${ }^{12}$.

Нравственное обоснование запрета допрашивать защитника об обстоятельствах, которые стали ему известны при осуществлении функции защиты, было дано А.Ф.Кони, который по данному поводу писал: «Между защитником и тем, кто в тоске и тревоге от грозно надвинувшегося обвинения обращается к нему в надежде на помощь, устанавливается тесная связь доверия и искренности. Защитнику открываются тайники души, ему стараются разъяснить свою виновность или объяснить свое падение и свой скрываемый от других позор такими подробностями личной жизни, по отношению к которым слепая Фемида должна быть и глухою» ${ }^{13}$.

Небезынтересно отметить, что в Проекте новой редакции УУС предлагалось производить допрос присяжных поверенных, если подсудимые ходатайствовали об этом, обосновывалось это следующим образом: «Недопущение

\footnotetext{
10 Ожегов С.И. Словарь русского языка. М., 1989. C. 282,488 .

11 Квачевский А. Об уголовном преследовании, дознании и предварительном исследовании преступлений по судебным уставам 1864 г. В 3-х чч. Часть 3. (Вып. второй), 1870. С. 452.

12 Викторский С. И. Русский уголовный процесс. М., 1911. C. 215.

13 Кони А.Ф. Нравственные начала в уголовном процессе // А.Ф. Кони Собр соч.: В 8-ми тт. Том 4. М., 1968. C. 53-54.
}

защитника сообщать признания подсудимого составляет изъятие из общего правила об обязанности каждого свидетельствовать перед органами судебной власти обо всем, что ему известно по данному делу, и составляет подчинение публичного интереса интересам частного лица, потому в случае отказа сего последнего от такой прерогативы не представляется уже оснований настаивать на ее соблюдении, вопреки желанию заинтересованного лица» ${ }^{14}$.

Согласно ст. 705 УУС «муж или жена обвиняемого лица, родственники по прямой линии, восходящей или нисходящей, а также родные его братья и сестры могут устранить себя от свидетельства, если же не пожелают воспользоваться сим правом, то допрашиваются без присяги».

Составители УУС, комментируя положения ст. 705, отмечали, что «в видах ограждения ненарушимости семейственного союза, составляющего основу всякого общежития, не следует требовать свидетельства от лиц, состоящих с подсудимым в супружестве или родстве ... Как бы ни была велика их решимость дать беспристрастные показания, но чувство любви, связывающее их с подсудимым, может против воли их подавить требование совести. Закон не дает никого ставить в положение, угрожающее явной опасностью клятвопреступления» ${ }^{15}$.

Характеризуя нравственное значение данного положения, А.Ф. Кони писал: «Закон щадит те чувства, которые даже при сознании свидетелем виновности подсудимого или наличности изобличающих его факторов, заставляли бы нередко сердце дающего показания обливаться слезами и кровью или искать облегчения своего тяжелого положения во лжи. В человеческом взгляде закона на таинственный голос крови или супружеской привязанности заключается даже как бы признание допустимости лжи, которая в известных случаях более близка к внутренней правде жизни, чем объективная и холодная истина» ${ }^{16}$.

УУС также не допускал совмещения процессуального статуса свидетеля с исполнением обязанностей прокурора, защитника подсудимого или поверенного, частного обвинителя или гражданского истца (ст. 709).

Кроме указанных выше субъектов в Проекте УУС предлагалось не допускать к свидетельству «врачей, акушеров и повивальных бабок в отношении к тайне, сообщенной им при исполнении обязанностей их звания». В оконча-

\footnotetext{
14 Проект новой редакции Устава уголовного судопроизводства. С. 235.

15 Судебные уставы 20 ноября 1864 года. С. 250.

16 Кони А.Ф. Указ. соч. С. 52.
} 
тельную редакцию УУС данное положение не вошло, поскольку, по мнению Государственного Совета, «освобождение этих лиц от свидетельства весьма часто служило бы важным препятствием к обнаружению истины и к сокрытию их соучастия или пособия в совершенном преступлении» ${ }^{17}$.

По общему правилу свидетелей допрашивали «на месте производства следствия» кроме тех случаев, когда свидетели по болезни или другим причинам не могли явиться к следствию, тогда они допрашивались по месту жительства (ст. 433 УУС).

Если возникала необходимость допросить нескольких свидетелей, проживавших в одном селении («околотке»), то допрос производился по месту их нахождения (ст. 434 УУС); воспитанники закрытых учебных заведений допрашивались по месту учебы. Министры, губернаторы и другие высокопоставленные чиновники пользовались привилегией быть допрошенными по месту их жительства (ст. 433 УУС).

Для явки свидетеля устанавливалось время, в которое он был свободен от своих занятий (ст. 437 УУС). Служебные обязанности или другие занятия свидетелей не освобождали их ни от явки, ни от денежного взыскания за неявку (ст. 438 УУС). Однако ст. 388 УУС устанавливала законные причины неявки свидетелей, такими признавались: лишение свободы, стихийные бедствия, «нашествие неприятеля», эпидемии, болезнь, несчастный случай, смерть или тяжелая болезнь близких родственников, неполучение или несвоевременное получение повестки. В случае неявки свидетеля без уважительных причин следователь вправе был наложить на свидетеля денежное взыскание на сумму до пятидесяти руб. и послать вторичную повестку. Если свидетель снова не являлся в срок, то он принудительно приводился к следователю. Следователь мог освободить от денежного взыскания свидетеля, если он представлял в двухнедельный срок доказательства о законных причинах неявки (ст. 440 УУС).

Перед допросом следователь предупреждал свидетеля о необходимости «показать всю правду» (ст. 443 УУС). В случае если свидетель не знал языка, на котором велся допрос, следователь приглашал лицо, сведущее в этом языке (ст. 410 УУС).

В судебном заседании свидетели допрашивались порознь. До начала судебного разбирательства свидетелей удаляли из зала судебного заседания. Перед началом допроса судья предупреждал свидетелей об уголовной ответственности за дачу ложных показаний. Свиде-

17 Судебные уставы 20 ноября 1864 года. С. 255. тель должен был рассказать все известное ему по делу. Не допускались ссылки на сведения, полученные от других лиц, если свидетель не мог указать источник своей осведомленности (ст. 718 УУС).

Свидетели допрашивались под присягой за некоторыми исключениями.

Составители Судебных Уставов отмечали, что присяга «по важности и священному значению своему должна сопровождаться возможной торжественностью» ${ }^{18}$.

На предварительном следствии свидетели обычно допрашивались без присяги, кроме следующих случаев:

«1) когда свидетель собрался в дальний путь и возвращение его может замедлиться;

2) когда свидетель находится в болезненном состоянии, угрожающем опасностью его жизни;

3) когда свидетель имеет жительство вне округа того суда, которому подсудно дело, и притом в такой отдаленности от места судебных заседаний, что ему без особенного затруднения явиться невозможно» (ст. 442 УУС).

На суде же свидетели, как правило, приводились к присяге. Свидетель православного вероисповедания приводился к присяге священником, который «внушал свидетелю святость присяги» (ст. 713 УУС). Свидетели не православного вероисповедания приводились к присяге в соответствии с догматами и обрядами их веры духовным лицом их вероисповедания (ст. 714 УУС). Если же в месте заседания суда не было духовного лица того вероисповедания, к которому принадлежал свидетель, то он к присяге приводился председательствующим судьей (ст. 715 УУС).

Относительно значения присяги и ее влияния на честность и добросовестность свидетеля в литературе высказывались различные мнения.

Так, Д.Г. Тальберг отрицательно относился к присяге, полагая, что присяга может вводить суд в заблуждение, поскольку показанию под присягой отдается предпочтение перед показанием без присяги ${ }^{19}$.

И.Я. Фойницкий рассматривал присягу как институт, опасный для правосудия, считая его остатком прежних времен наряду с ордалиями, поскольку суд, «имея перед собою данную присягу, успокаивается на этом и не заботится об индивидуальной поверке личности показывающего». Кроме того, по мнению И.Я. Фойницкого, присяга представляется «даже для человека верующего тягостной, требуя от

\footnotetext{
18 Судебные уставы 20 ноября 1864 года. С. 443.

19 Тальберг Д.Г. Русское уголовное судопроизводство. В 2-х тт. Том 2. - Киев, 1889. С. 147-148.
} 
него часто призвание имени Божества по сравнительно маловажным обстоятельствам и порождая мысль, что без этого слово его само по себе не пользуется доверием» ${ }^{20}$.

В.К. Случевский, наоборот, считал, что «страх навлечь на себя лжеприсягой небесный гнев для человека верующего есть самый могущественный стимул правдивости, способный заставить его пренебречь всякими посторонними интересами. К этому присоединяется и страх гнева земного правосудия, так как лжеприсяга объявляется деянием наказуемым» ${ }^{21}$. А.В. Скопинский также исходил из того, что «даже нетвердые в религии люди, в силу торжественности, которою обставляется присяга и благодаря силе самих слов присяги, не остаются без воздействия на их совесть со стороны этого прекрасного обряда» ${ }^{22}$.

К.К. Арсеньев отмечал, что присяга удерживает или, по крайней мере, должна удерживать свидетеля от ложных, преувеличенных или неполных показаний ${ }^{23}$.

УУС предусматривал довольно широкий круг свидетелей, которые не допускались к свидетельствованию под присягой. В соответствии со ст. 706 УУС это:

«1) отлученные от церкви по приговору духовного суда;

2) малолетние, не достигшие четырнадцати лет;

3) слабоумные, не понимающие святости присяги:

4) лица евангелического исповедания, пока они не конфирмированы».

В соответствии со ст. 712 УУС от присяги освобождались: священнослужители всех христианских вероисповеданий и лица, принадлежащие к исповеданиям и вероучениям, не приемлющим присяги - вместо присяги эти лица давали обещание показать правду по чистой совести.
Кроме того, не допускались к свидетельствованию под присягой в случаях предъявления какой-либо из сторон отвода:

1) лишенные по суду всех прав состояния или всех особенных прав и преимуществ;

2) потерпевшее от преступления лицо, хотя бы оно участвовало в деле, а также муж и жена его, родственники по прямой линии и родные его братья или сестры;

3) другие по боковым линиям родственники как потерпевшего лица, так и подсудимого, в третьей и четвертой степенях, и свойственники обеих сторон в первых двух степенях;

4) состоящие с участвующими в деле лицами в особенных отношениях или по усыновлению, или по опеке, или по управлению одним из них делами другого, а также имеющими тяжбу с кем-либо из участвующих в деле лиц;

5) раскольники - по делам лиц, обратившихся из раскола в православие (ст. 707 УУС);

6) наследники подсудимого по его отводу, в какой бы степени родства они не состояли с ним, когда он судится за преступление, разрушающее все права состояния (ст. 708 УУС).

Если свидетели допрашивались без присяги, то председательствующий судья делал «увещевание», в котором напоминал им о необходимости отрешиться «от всякого влияния на них вражды, дружбы или страха» и говорить «сущую правду и только одну правду, не увеличивая и не уменьшая известных им обстоятельств, а, показывая все так, как что случилось» (ст. 717 УУС). В этих случаях присягу заменяло торжественное обещание «показать всю правду по чистой совести».

Итак, УУС предусматривал достаточно хорошо разработанный комплекс уголовно-процессуальных норм, регулировавших процессуальный статус свидетеля, многие из них вошли в современный УПК РФ, фактически УУС заложил основы современного института свидетельствования.

\section{Библиография}

1. Арсеньев К.К. Судебное следствие: сборник практических заметок. СПб.: Тип. В. Демакова, 1870. - 361 c.

2. Викторский С.И. Русский уголовный процесс. М.: Казенная железнодорожная типография Московского узла, 1911. - 320 с.

3. Квачевский А. Об уголовном преследовании, дознании и предварительном исследовании преступлений по судебным уставам 1864 г.: В 3-х чч. Часть 3. (Вып. второй). СПб.: Тип. Ф.С. Сущинского, 1870. - 319 с.

\footnotetext{
20 Фойницкий Указ. соч. С. 261.

21 Случевский В.К. Учебник русского уголовного судопроизводства. Судоустройство-Судопроизводство. СПб., 1910. С. 433.

22 Скопинский А.В. Указ. соч. С. 59.

23 Арсеньев К.К. Судебное следствие: сборник практических заметок. СПб., 1870. С. 230.
} 
4. Кони А.Ф. Нравственные начала в уголовном процессе // Кони А.Ф. Собр. соч.: В 8-ми тт. Том 4. М.: Юрид. лит., 1968. - С. 33-69.

5. Макалинский П.В. Практическое руководство для судебных следователей, состоящих при окружных судах: В 2-х чч. Часть І. СПб.: Типография Н.А. Лебедева, 1894. - 697 с.

6. Ожегов С.И. Словарь русского языка. М.: Русский язык, 1989. - 750 с. а.Проект новой редакции Устава уголовного судопроизводства, составленный Высочайше утвержденною Комиссиею для пересмотра законоположений по судебной части. СПб.: Сенатская типография, 1900. $513 \mathrm{c}$.

7. Скопинский А.В. Свидетели по уголовным делам: пособие для практиков. М.: Изд-е книжного магазина И.Г. Голубева, 1911. - 194 с.

8. Случевский В.К. Учебник русского уголовного судопроизводства. Судоустройство-Судопроизводство. СПб.: Типография М. М. Стасюлевича, 1910. - 664 с.

9. Тальберг Д.Г. Русское уголовное судопроизводство: В 2-х тт. Том 2. Киев: Изд-е И.Н. Кушнеров и Ко, 1889. - 318 с.

10. Фойницкий И.Я. Курс уголовного судопроизводства: В 2-х тт. Том 2. СПб.: Сенатская типография, 1912. - 567 с.

11. Энциклопедический словарь / Изд-ли Ф.А. Брокгауз, И.А. Ефрон. В 82-х тт. Том 64. СПб.: Типолитография И.А. Ефрона, 1901. - 657 с.

\section{References}

1. Arsen'ev K.K. Sudebnoe sledstvie: sbornik prakticheskikh zametok. SPb.: Tip. V. Demakova, 1870. $361 \mathrm{~s}$.

2. Viktorskii S.I. Russkii ugolovnyi protsess. M.: Kazennaya zheleznodorozhnaya tipografiya Moskovskogo uzla, 1911. - $320 \mathrm{~s}$.

3. Kvachevskii A. Ob ugolovnom presledovanii, doznanii i predvaritel'nom issledovanii prestuplenii po sudebnym ustavam 1864 g.: V 3-kh chch. Chast' 3. (Vyp. vtoroi). SPb.: Tip. F.S. Sushchinskogo, 1870. - $319 \mathrm{~s}$.

4. Koni A.F. Nravstvennye nachala v ugolovnom protsesse // Koni A.F. Sobr. soch.: V 8-mi tt. Tom 4. M.: Yurid. lit., 1968. - S. 33-69.

5. Makalinskii P.V. Prakticheskoe rukovodstvo dlya sudebnykh sledovatelei, sostoyashchikh pri okruzhnykh sudakh: V 2-kh chch. Chast' I. SPb.: Tipografiya N.A. Lebedeva, 1894. - $697 \mathrm{s.}$

6. Ozhegov S.I. Slovar' russkogo yazyka. M.: Russkii yazyk, 1989. - 750 s. a.Proekt novoi redaktsii Ustava ugolovnogo sudoproizvodstva, sostavlennyi Vysochaishe utverzhdennoyu Komissieyu dlya peresmotra zakonopolozhenii po sudebnoi chasti. SPb.: Senatskaya tipografiya, 1900. - $513 \mathrm{~s}$.

7. Skopinskii A.V. Svideteli po ugolovnym delam: posobie dlya praktikov. M.: Izd-e knizhnogo magazina I.G. Golubeva, 1911. - 194 s.

8. Sluchevskii V.K. Uchebnik russkogo ugolovnogo sudoproizvodstva. Sudoustroistvo-Sudoproizvodstvo. CPb.: Tipografiya M. M. Stasyulevicha, 1910. - 664 s.

9. Tal'berg D.G. Russkoe ugolovnoe sudoproizvodstvo: V 2-kh tt. Tom 2. Kiev: Izd-e I.N. Kushnerov i Ko, 1889. - $318 \mathrm{~s}$.

10. Foinitskii I.Ya. Kurs ugolovnogo sudoproizvodstva: V 2-kh tt. Tom 2. SPb.: Senatskaya tipografiya, 1912. - $567 \mathrm{~s}$.

11. Entsiklopedicheskii slovar' / Izd-li F.A. Brokgauz, I.A. Efron. V 82-kh tt. Tom 64. SPb.: Tipo-litografiya I.A. Efrona, 1901. - 657 s. 